University of Massachusetts Amherst

ScholarWorks@UMass Amherst

Environmental Conservation Faculty Publication

Series

Environmental Conservation

2021

\title{
Invaders for sale: the ongoing spread of invasive species by the plant trade industry
}

\author{
Evelyn M. Beaury \\ University of Massachusetts Amherst \\ Madeline Patrick \\ University of Massachusetts Amherst \\ Bethany A. Bradley \\ University of Massachusetts Amherst
}

Follow this and additional works at: https://scholarworks.umass.edu/nrc_faculty_pubs

Part of the Environmental Monitoring Commons, and the Natural Resources and Conservation Commons

\section{Recommended Citation}

Beaury, Evelyn M.; Patrick, Madeline; and Bradley, Bethany A., "Invaders for sale: the ongoing spread of invasive species by the plant trade industry" (2021). Frontiers In Ecology And The Environment. 433.

https://doi.org/10.1002/fee.2392

This Article is brought to you for free and open access by the Environmental Conservation at ScholarWorks@UMass Amherst. It has been accepted for inclusion in Environmental Conservation Faculty Publication Series by an authorized administrator of ScholarWorks@UMass Amherst. For more information, please contact scholarworks@library.umass.edu. 


\section{Research Communications}

Invaders for sale: the ongoing spread of invasive species by the plant trade industry Evelyn M Beaury ${ }^{1 *}$, Madeline Patrick ${ }^{2}$, and Bethany A Bradley ${ }^{1,2}$

${ }^{I}$ Organismic and Evolutionary Biology, University of Massachusetts-Amherst, Amherst, MA

*(ebeaury@umass.edu); ${ }^{2}$ Department of Environmental Conservation, University of

Massachusetts-Amherst, Amherst, MA

\section{Running heads:}

EM Beaury et al.

Invasive species and the plant trade industry

The sale of ornamental nonnative plants is a primary pathway of invasive plant introduction into the US. As a result, many nonnative plants have been identified as noxious weeds by federal and state governments, or as problematic invasive plants by agencies and nonprofit organizations. However, it is unclear whether identifying a species as invasive has curtailed its sale as an ornamental. Using the Google search engine and a database of nursery catalogs, we found that $61 \%$ of 1285 plant species identified as invasive in the US remain available through the plant trade, including $50 \%$ of state-regulated species and $20 \%$ of federal noxious weeds. Vendors offering invasive plants were located in all lower 48 states. The widespread availability of invasive plants in the US is likely a symptom of disjointed state regulations that fail to protect ecosystems and economies. Regional regulation coupled with outreach to growers and consumers is needed to reduce the ongoing propagation of invasive plants in the US.

Front Ecol Environ 2021;

More than half of the world's flora has been introduced to novel regions for use in agriculture, medicine, and gardening (Mack and Erneberg 2002; Van Kleunen et al. 2018; Guo et al. 2019). The propagation of plants and plant products is a valuable component of economies from local to global scales (Hulme et al. 2018; Van Kleunen et al. 2018), but plant trade has unintended consequences. When relocated outside their native range, some ornamental plants escape cultivation, spread into natural areas, and become invasive, with potential negative impacts on the environment and human health (Van Kleunen et al. 2018). Nearly $40 \%$ of the invasive plants now in the US were originally introduced as ornamentals (Lehan et al. 2013), and these species affect nearly every ecosystem of the country and continue to expand into new areas (Allen and Bradley 2016).

Once discovered to be invasive, plant imports into the US can be prohibited through border inspections (eg the US Department of Agriculture Animal and Plant Health Inspection Service [APHIS] Plant Protection and Quarantine Program; Reichard and White 2001) or their 
sales can be regulated internally by government agencies at the federal and state levels (Beck et al. 2008; Hulme et al. 2018). Because management is costly, regulation is typically restricted to those invasive species with the most severe negative impacts (Beck et al. 2008). For example, the US Federal Noxious Weed Act identifies 98 plant species and seven genera considered to be the greatest threats to US natural resources; it is illegal to grow or sell these plants anywhere in the US. Most states have similar regulatory lists intended to reduce the spread of high impact invasive plants, and there are a number of unregulated nonnative plants identified as invasive and managed by state and federal agencies or conservation organizations. These regulatory and nonregulatory lists combine to over a thousand species considered invasive in the US (USDA PLANTS Database [https://plants.usda.gov/home], Invasive Plant Atlas [www.invasiveplantatlas.org]).

The purpose of regulatory and nonregulatory lists and the identity of listed species varies markedly across states (Beck et al. 2008; Quinn et al. 2013). Some regulatory lists focus on agricultural weeds (McCubbins et al. 2013), whereas others focus on ornamental species whose introduction could reasonably be prevented through nursery inspections (G Fish and D Cygan pers comm). Other regulatory lists include invasive plants likely to impact natural areas, in which the list is intended to prioritize species for management and prevent spread to new areas (M Renz pers comm). Unregulated invasive plants include species for which insufficient data exist to categorize them as invasive, species that have been reported as invasive by local experts (eg by National Park Service ecologists), and species with high market value to the ornamental plant industry (Reichard and White 2001; Beck et al. 2008; Quinn et al. 2013).

Because plant invasions often span political boundaries (eg state borders), this piecemeal approach to regulation and management likely enables some invasive plants to remain on the market. For example, species identified as invasive and regulated in certain states can still legally be sold elsewhere (Reichard and White 2001; Hulme et al. 2018). It is therefore unlikely that horticulturists will abandon a species with high market value unless it is consistently regulated (Reichard and White 2001; Knight et al. 2011; Hulme et al. 2018). Moreover, inconsistent state lists make it difficult for plant traders and consumers to stay informed about which species are invasive (Reichard and White 2001; Burt et al. 2007). Popular ornamentals are often easy-togrow yet hardy species that are resistant to pests and pathogens (Mack 2005; Van Kleunen et al. 2018; Guo et al. 2019). Because these traits are also associated with successful invaders (Van Kleunen et al. 2018), and given that there are over a thousand plant species considered invasive in the US, even well intentioned growers and consumers may continue to promote invasions (Dehnen-Schmutz et al. 2007).

It has been 20 years since the ornamental plant trade was first identified as a primary source of invasive plants in the US (Reichard and White 2001). Following this discovery, numerous strategies to reduce ornamental invasions have been put forth, including increasing regulations (Lodge et al. 2006), creating "green lists" of native alternatives to invaders (DehnenSchmutz 2011), and voluntary initiatives encouraging growers to sell noninvasive plants (Burt et al. 2007; Hulme et al. 2018). Here, we examined how well these regulatory and ethical 
guidelines serve to limit the spread of invasive plants by identifying (1) the proportion of plants identified as invasive in the US that remain offered for sale as ornamentals, (2) the spatial extent of these sales across the lower 48 states, and (3) which sales co-occur with federal and state regulations.

\section{Methods}

We compiled a list of plants defined as invasive and/or noxious in the lower 48 US (WebTable 1). Regulated species were identified by the USDA federal noxious weed list or by state invasive plant, noxious weed, and noxious seed laws. Unregulated species included additional species listed by the Invasive Plant Atlas. Collectively, these sources represent the pool of species considered harmful to US agriculture, natural resources, public health, or the environment (Beck et al. 2008). We excluded nonvascular species, taxa identified to genus only, and species invasive only in Hawaii or Alaska (although all federal noxious weeds were included).

We conducted a standardized search for opportunities to purchase all species $(n=1285)$ using Google and Plant Information Online (previously accessible via https://plantinfo.umn.edu). Plant Information Online is a University of Minnesota database that documents retail and wholesale nursery catalogs in the US. As of July 2021, the database is undergoing maintenance; please contact the University of Minnesota Horticultural Library for updates on access. Each species was searched for once between August 2017 and December 2019, and therefore results represent a static period in time. We considered a species to be available through the plant trade if it was offered for sale by at least one vendor.

Using Google, we searched for each species' scientific name (and synonymous scientific names listed by the USDA PLANTS Database using an "OR" statement) and common names followed by the key words "for sale", "plant for sale", and "seeds for sale" in separate searches. For each search string, we recorded offers for sale in the first three pages of Google results. We only recorded an offer for sale if the vendor was located within the lower 48 states and listed the full scientific name (species of the same genus often share common names). We distinguished between two types of vendors based on their websites: (1) commercial nurseries with a street address for a storefront or garden center where one can purchase plants and seeds (these vendors often sold online as well); and (2) e-commerce trade, where vendors or individuals offered plants or seeds online only and did not appear to have a storefront. For each vendor offering an invasive plant, we recorded the name of the seller, their location if available, and for nurseries, whether or not the seller labeled the plant as problematic or restricted shipping the plant to certain states.

Using the Plant Information Online website, we searched for each species' scientific name and synonyms (this database did not allow searches by common name) and if a species was offered for sale, we recorded each seller's name and location. This database included nurseries with on-the-ground locations (ie no vendors were online only) and did not provide information on whether the plant was labeled as problematic or could not be shipped. No information was found on the Plant Information Online website for 125 of the 1285 species. 
Many invasive plants on our list were introduced into the US accidentally (Lehan et al. 2013) and are therefore unlikely to be currently for sale or to have ever been for sale. To better assess whether invasive species originally introduced as ornamentals remain on the market, we compared our list to plants identified by Lehan et al. (2013) as having been introduced through the plant trade. We used R (v3.6.0) to generate summary statistics and ArcGIS (v10.6.1) to create map visualizations in a contiguous Albers equal-area conic projection.

\section{Results}

Of the 1285 plant taxa identified as invasive in the US, we found $778(61 \%)$ available for purchase (Table 1). These species were offered by 1330 different vendors, resulting in more than 15,000 opportunities to purchase invasive plants across all lower 48 states (Figure 1). The majority of vendors were retail or wholesale nurseries $(n=1081,81 \%)$ as opposed to ecommerce $(n=249,19 \%)$; however, the greatest number of species for sale $(n=281)$ was on eBay, with other large online marketplaces also common distributors (eg Amazon, Etsy, eCRATOR). Few vendors labeled invasive species as problematic ( $4 \%$ of Google nursery sales) or identified restrictions on shipping species to certain states (16\% of Google nursery sales). The number of vendors selling each species varied substantially but declined with the number of states regulating a species' movement (Figure 2).

\section{Regulated plant sales}

About half of the invasive plants on our lists (688 of the 1285) were regulated by one or more state governments or by the federal government, suggesting they are problematic enough to warrant regulation and management. Nonetheless, nearly $50 \%$ of these $(n=343)$ were offered for sale somewhere in the US (Table 1), amounting to 5539 opportunities to purchase regulated invasive plants from 916 vendors. The regulated species offered for sale by the most vendors included Chinese silvergrass (Miscanthus sinensis), available from 140 vendors in 37 states, including Connecticut, where it is regulated; common sunflower (Helianthus annuиs), available from 122 vendors in 37 states, including Iowa, where it is regulated; butterflybush (Buddleja davidii), available from 109 vendors in 33 states, including Oregon, where it is regulated; and Japanese barberry (Berberis thunbergii), available from 109 vendors in 28 states, including Connecticut, Minnesota, and Wisconsin, where it is regulated.

Most instances in which vendors offered regulated plants (93\%) occurred outside of states where species were regulated. However, we found 146 species offered for sale in the same state where their sale was regulated (Figure 1c). These species were available from 232 vendors, resulting in 382 unique opportunities to purchase invasive plants despite state regulations. This occurred in 34 states, most frequently in Wisconsin, Ohio, and Oregon. Japanese barberry (Berberis thunbergii, listed and available in Connecticut, Minnesota, and Wisconsin) and glossy buckthorn (Frangula alnus, listed and available in Connecticut, New York, Illinois, Minnesota, Ohio, and Wisconsin) were most frequently offered in states regulating their sale (Figure 3). We also documented 856 cases in which a species was offered for sale in a state directly neighboring 
another state where the species was regulated; this occurred for 221 regulated species across 447 vendors in 47 states, with North Dakota being the sole exception.

We found 20 of 98 (20\%) federal noxious weeds offered for sale by 76 vendors, resulting in 81 opportunities to purchase noxious weeds in 30 states. Half of these cases were vendors selling a cultivar of the noxious weed cogongrass (Imperata cylindrica).

\section{Unregulated plant sales}

The remaining 597 species were identified as invasive by the Invasive Plant Atlas. We found 435 (73\%) of these offered for sale by 1130 vendors distributed across all lower 48 states. The unregulated species offered most frequently included panicled hydrangea (Hydrangea paniculata) and Japanese maple (Acer palmatum).

\section{Comparison to original introduction pathway and date}

Lehan et al. (2013) reported introduction pathways for 916 of the species we searched; 434 of these species $(47 \%)$ were deliberately introduced via pathways linked to plant trade: forage crops, ornamentals, forestry plantings, turfgrass, aquarium plants, or in wild seed mixes. Of these deliberately introduced species, 360 (83\%) were still available for sale. Most were introduced in the 20th century, although the initial introduction of several ornamentals dates back to the 15 th16 th centuries.

\section{Discussion}

It has been known for decades that the sale of nonnative ornamental plants is the primary pathway through which invasive plants are introduced into the US (Reichard and White 2001; Mack and Erneberg 2002). Despite repeated calls for voluntary and regulatory change to the plant trade industry (Reichard and White 2001; Burt et al. 2007; Knight et al. 2011), imports of new exotic plants into the US continue to rise (Bradley et al. 2012; Seebens et al. 2017). We documented thousands of opportunities to purchase invasive plants in the US, including federaland state-regulated species and ornamental plants that were identified as invasive decades ago. By quantifying the extent of access to invasive plants through the plant trade, our analysis shows that much greater effort is needed to reduce the sale of invasive plants in the US.

All species included in our analysis were identified as invasive on regulatory or nonregulatory lists, but these species likely encompass a range of impacts, as well as market value to the plant trade. Although a consistent way to compare all species' invasiveness is lacking, states often select species for regulation following an assessment of negative impacts to natural resources, agriculture, or the environment (Buerger et al. 2016), and therefore the number of states in which a species is regulated can serve as a proxy for its potential impacts (though many high-impact species remain unregulated). Similarly, although we did not record the costs of purchasing these plants, the number of different vendors offering a species for sale can inform how commonly a species is distributed, which can serve as a proxy for its market value. 
Variation in the number of states where a species is regulated and the number of vendors offering it for sale (Figure 2) can serve as a framework for prioritizing species for regulation, including assessing the likelihood of phasing species out of cultivation given how popular they are as ornamentals. For example, Japanese maple and panicled hydrangea were offered by the most vendors, suggesting that these plants are popular with consumers and may be highly profitable for vendors. According to the Invasive Plant Atlas, both species have been observed growing outside of cultivation in the northeastern US, but neither is regulated in the US; because their impacts may not be widespread, they could be considered low priority for management.

Species that are widely distributed as ornamentals and have well-documented negative impacts present a larger challenge for regulation (Knight et al. 2011). For instance, Japanese barberry is a popular ornamental shrub that was offered for sale by more than 100 vendors in 33 different states, including three states where it is regulated. This species, which has naturalized in more than half of the lower 48 US states (Bargeron and Moorhead 2007), has the potential to form dense thickets, outcompete native species, and carry ticks that transmit Lyme disease (Williams et al. 2009). Barberry is regulated in nine states and could spread into the Northeast, Upper Midwest, and Pacific Northwest (Allen and Bradley 2016). For states in these regions, marketing native alternatives to barberry may be both profitable and environmentally friendly.

We found fewer vendors selling species that might be more likely to have widespread impacts considering their regulation in multiple states (Figure 2; Beck et al. 2008). These species included glossy buckthorn (regulated in ten states), common corncockle (Agrostemma githago; 19 states), tatarian honeysuckle (Lonicera tatarica; 12 states), yellow iris (Iris pseudacorus; 12 states), and several others (Figure 2). Considering that these are considered to be problematic species in multiple states and that they were offered for sale by a smaller number of vendors, ending their sales more broadly across the US should be a top priority for regulation and management. Special attention should be paid to species that were available for purchase in the same state where they are regulated; for instance, glossy buckthorn was frequently found for sale in states in which it is regulated, or in neighboring states (Figure 3). Although some of these sales may involve a sterile cultivar (which may not be fully sterile; Knight et al. 2011), inconsistent regulation of buckthorn provides opportunities for this species to continue to spread (Figure 3).

Across the US, disjunct regulations allow plants to be sold in states adjacent to where they are regulated, leading to high invasion risk in neighboring states with similar environments. In 47 of the lower 48 states, we found regulated species offered for sale in an adjacent state; this lack of regulatory consistency between adjacent states may result in invasive plants being introduced into new areas and creates barriers for growers to comply with guidelines. For example, horticulturists have reported difficulty accessing up-to-date lists of what is invasive in their area (Burt et al. 2007), which reduces the ability of nurseries to comply with regulations or participate in voluntary codes of conduct (Yue et al. 2011). However, local-scale studies have reported that when informed about the extent of invader impacts, both growers and consumers preferred native plants (Burt et al. 2007; Yue et al. 2011; Oele et al. 2015). More transparent and 
consistent lists of invasive plants can therefore improve guidance to the ornamental plant trade industry.

The development of regional lists of prohibited plants is one potential solution to facilitate the ornamental industry's awareness of regulations and states' capacity to reduce invasive plant spread (Lodge et al. 2006). The percentage of regulatory species available for purchase was lower than the percentage of unregulated species (Table 1), and most regulated plants were offered for sale outside of states where they were prohibited. This suggests that regulations effectively reduce within-state invasive plant sales, and that suppliers and consumers are motivated to reduce ecological harm when provided direction from their state. However, inconsistent information, variation in regulations, and lack of enforcement allow invasive species to remain on the market (Reichard and White 2001). Consequently, expanding regulations to include regionally prohibited species may result in a more consistent and complete regulatory landscape. Several states have worked toward this under direction from the National Association of Invasive Plant Councils, which coordinates activities within and between state and regional invasive plant councils. At the national scale, we found vendors selling 20 of the 98 federally regulated species, but only three of these (Imperata cylindrica, Prosopis velutina, and Rubus moluccanus) were offered by more than five vendors across the US. In general, the percentage of federally regulated species that were available was much lower than that of state- or unregulated species (Table 1), suggesting that more direction at regional and national levels may result in fewer holes in the current approach to regulating invasive plants (Lodge et al. 2006).

The most concerning case of federal noxious weed sales was the widespread availability of cogongrass, which was offered by 33 vendors across 17 states. Cogongrass has been on the federal noxious weed list for more than a decade, and it is labeled as one of the International Union for Conservation of Nature's "world's most invasive plants", with negative impacts to native biodiversity, fire regimes, and nutrient cycling (Estrada and Flory 2015; Fusco et al. 2019). We often found offers of the "red baron" or "rubra" cultivar of cogongrass, which is exempt from regulation in some states because it has been described as a sterile, slow-growing cultivar. However, this cultivar has the potential to regain invasive tendencies (Cseke and Talley 2012) and similar escapes of "sterile" cultivars have been documented for other ornamental invaders, such as glossy buckthorn, burning bush (Euonymus alatus), and Japanese barberry (Knight et al. 2011). Continuing to plant cultivars for which sterility is uncertain has the potential to exacerbate active invasions.

In addition to risks associated with the sale of cultivars, the rise in e-commerce trade of invasive plants could seed future invasions, including in areas where conditions will become more suitable with climate change (Bradley et al. 2010). We observed very low rates of nurseries restricting plant shipments or labeling species as weedy or invasive. Plants available through large online marketplaces (such as eBay and Amazon) were often transient sales offered by individuals, which may make them more difficult to find and regulate (Humair et al. 2015). As a result, a single seller has the potential to ship plants to different regions of the US, including shipping plants that may be legally grown in their region but that are considered invasive 
elsewhere. For example, we documented more than a hundred vendors offering Chinese silvergrass for sale; although currently regulated only in Connecticut, this species is spreading rapidly throughout southern and Mid-Atlantic states (Bargeron and Moorhead 2007), with growing evidence that it outcompetes native species and exacerbates fires (Fusco et al. 2019). Considering its availability as an ornamental outside of its invaded range, there is high risk that Chinese silvergrass, and similarly distributed but unregulated species, will spread to new regions.

The ongoing sale of invasive ornamental plants documented here underscores the need for improved regulations and awareness of invasive species in the US. Potential solutions include increasing consistency in regulations, greater coordination among states at regional and national levels, and providing growers with transparent information to aid their efforts in reducing the spread of invasive plants. Although barriers to effective enforcement of federal and state regulations exist (eg lack of resources for regulation, high market value species; Knight et al. 2011), there are strong ecological and economic benefits to prohibiting the import of new exotic species that have the potential to become invasive (Keller et al. 2007) and to slowing the spread of species known to have negative impacts (Lodge et al. 2006).

\section{Acknowledgements}

We thank M Breviglia, E Lao, B Buckley, L Cleary, M Benoit, and M Liu for contributing to data collection, as well as A Bayer and members of the UMass Spatial Ecology Lab for their feedback. This work was supported by a US National Science Foundation Graduate Research Fellowship (grant \#1451512), by the US Geological Survey (grant \#G19AC00091), and by a Department of Interior Northeast Climate Adaptation Science Center graduate fellowship awarded to EMB.

\section{References}

Allen JM and Bradley BA. 2016. Out of the weeds? Reduced plant invasion risk with climate change in the continental United States. Biol Conserv 203: 306-12.

Bargeron CT and Moorhead DJ. 2007. EDDMapS - Early Detection and Distribution Mapping System for the Southeast Exotic Pest Plant Council. Wildland Weeds 10: 4-8.

Beck KG, Zimmerman K, Schardt JD, et al. 2008. Invasive species defined in a policy context: recommendations from the Federal Invasive Species Advisory Committee. Invas Plant Sci Mana 1: 414-21.

Bradley BA, Blumenthal DM, Early R, et al. 2012. Global change, global trade, and the next wave of plant invasions. Front Ecol Environ 10: 20-28.

Bradley BA, Blumenthal DM, Wilcove DS, and Ziska LH. 2010. Predicting plant invasions in an era of global change. Trends Ecol Evol 25: 310-18.

Buerger A, Howe K, Jacquart E, et al. 2016. Risk assessments for invasive plants: a midwestern US comparison. Invas Plant Sci Mana 9: 41-54.

Burt JW, Muir AA, Piovia-Scott J, et al. 2007. Preventing horticultural introductions of invasive plants: potential efficacy of voluntary initiatives. Biol Invasions 9: 909-23. 
Cseke LJ and Talley SM. 2012. A PCR-based genotyping method to distinguish between wildtype and ornamental varieties of Imperata cylindrica. JoVE-J Vis Exp; doi.org/10.3791/3265.

Dehnen-Schmutz K. 2011. Determining non-invasiveness in ornamental plants to build green lists. J Appl Ecol 48: 1374-80.

Dehnen-Schmutz K, Touza J, Perrings C, and Williamson M. 2007. A century of the ornamental plant trade and its impact on invasion success. Divers Distrib 13: 527-34.

Estrada JA and Flory SL. 2015. Cogongrass (Imperata cylindrica) invasions in the US: mechanisms, impacts, and threats to biodiversity. Global Ecol Conserv 3: 1-10.

Fusco EJ, Finn JT, Balch JK, et al. 2019. Invasive grasses increase fire occurrence and frequency across US ecoregions. P Natl Acad Sci USA 116: 23594-99.

Guo W-Y, van Kleunen M, Pierce S, et al. 2019. Domestic gardens play a dominant role in selecting alien species with adaptive strategies that facilitate naturalization. Global Ecol Biogeogr 28: 628-39.

Hulme PE, Brundu G, Carboni M, et al. 2018. Integrating invasive species policies across ornamental horticulture supply chains to prevent plant invasions. J Appl Ecol 55: 92-98.

Humair F, Humair L, Kuhn F, and Kueffer C. 2015. E-commerce trade in invasive plants. Conserv Biol 29: 1658-65.

Keller RP, Lodge DM, and Finnoff DC. 2007. Risk assessment for invasive species produces net bioeconomic benefits. P Natl Acad Sci USA 104: 203-07.

Knight TM, Havens K, and Vitt P. 2011. Will the use of less fecund cultivars reduce the invasiveness of perennial plants? BioScience 61: 816-22.

Lehan NE, Murphy JR, Thorburn LP, and Bradley BA. 2013. Accidental introductions are an important source of invasive plants in the continental United States. Am J Bot 100: 1287-93.

Lodge DM, Williams S, MacIsaac HJ, et al. 2006. Biological invasions: recommendations for US policy and management. Ecol Appl 16: 2035-54.

Mack RN. 2005. Predicting the identity of plant invaders: future contributions from horticulture. HortScience 40: 1168-74.

Mack RN and Erneberg M. 2002. The United States naturalized flora: largely the product of deliberate introductions. Ann Mo Bot Gard 89: 176-89.

McCubbins JSN, Endres AB, Quinn L, and Barney JN. 2013. Frayed seams in the "patchwork quilt" of American federalism: an empirical analysis of invasive plant species regulation. Environ Law 43: 35.

Oele DL, Wagner KI, Mikulyuk A, et al. 2015. Effecting compliance with invasive species regulations through outreach and education of live plant retailers. Biol Invasions 17: 270716.

Quinn LD, Barney JN, McCubbins JSN, and Endres AB. 2013. Navigating the "noxious" and "invasive" regulatory landscape: suggestions for improved regulation. BioScience 63: 12431. 
Reichard SH and White P. 2001. Horticulture as a pathway of invasive plant introductions in the United States - most invasive plants have been introduced for horticultural use by nurseries, botanical gardens, and individuals. BioScience 51: 103-13.

Seebens H, Blackburn TM, Dyer EE, et al. 2017. No saturation in the accumulation of alien species worldwide. Nat Commun 8: 1-9.

Van Kleunen M, Essl F, Pergl J, et al. 2018. The changing role of ornamental horticulture in alien plant invasions. Biol Rev 93: 1421-37.

Williams SC, Ward JS, Worthley TE, and Stafford KC. 2009. Managing Japanese barberry (Ranunculales: Berberidaceae) infestations reduces blacklegged tick (Acari: Ixodidae) abundance and infection prevalence with Borrelia burgdorferi (Spirochaetales:

Spirochaetaceae). Environ Entomol 38: 977-84.

Yue C, Hurley TM, and Anderson N. 2011. Do native and invasive labels affect consumer willingness to pay for plants? Evidence from experimental auctions. Agr Econ 42: 195-205.

\section{Supporting Information}

Additional, web-only material may be found in the online version of this article at

\section{Figure captions}



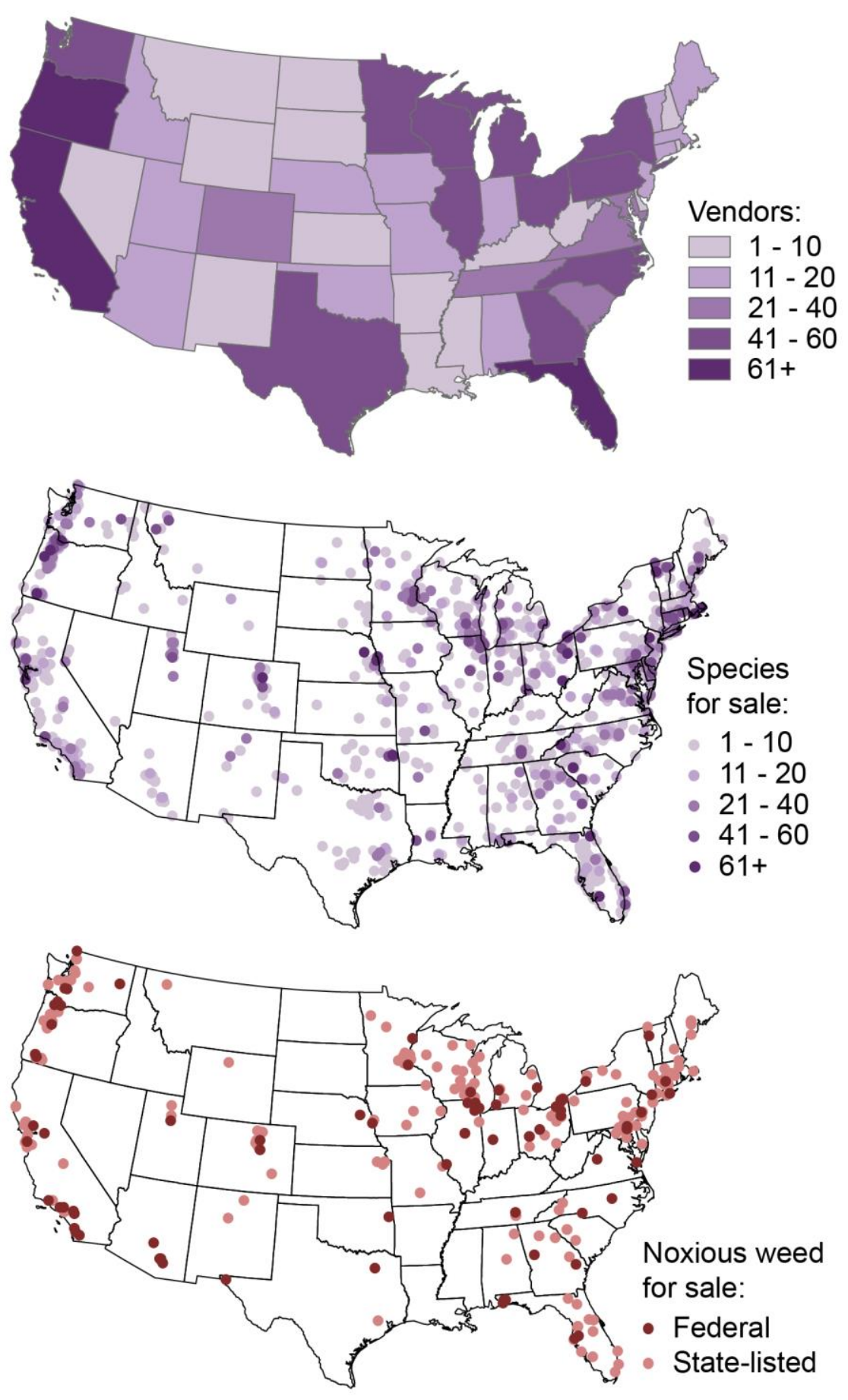

Figure 1. (a) The number of vendors offering invasive plants in each state. (b) The distribution of vendors offering invasive plants across the US; colors correspond to the number of invasive species available for sale by that vendor. (c) Vendors offering invasive species for sale within states where their trade is subject to federal or state regulations. 


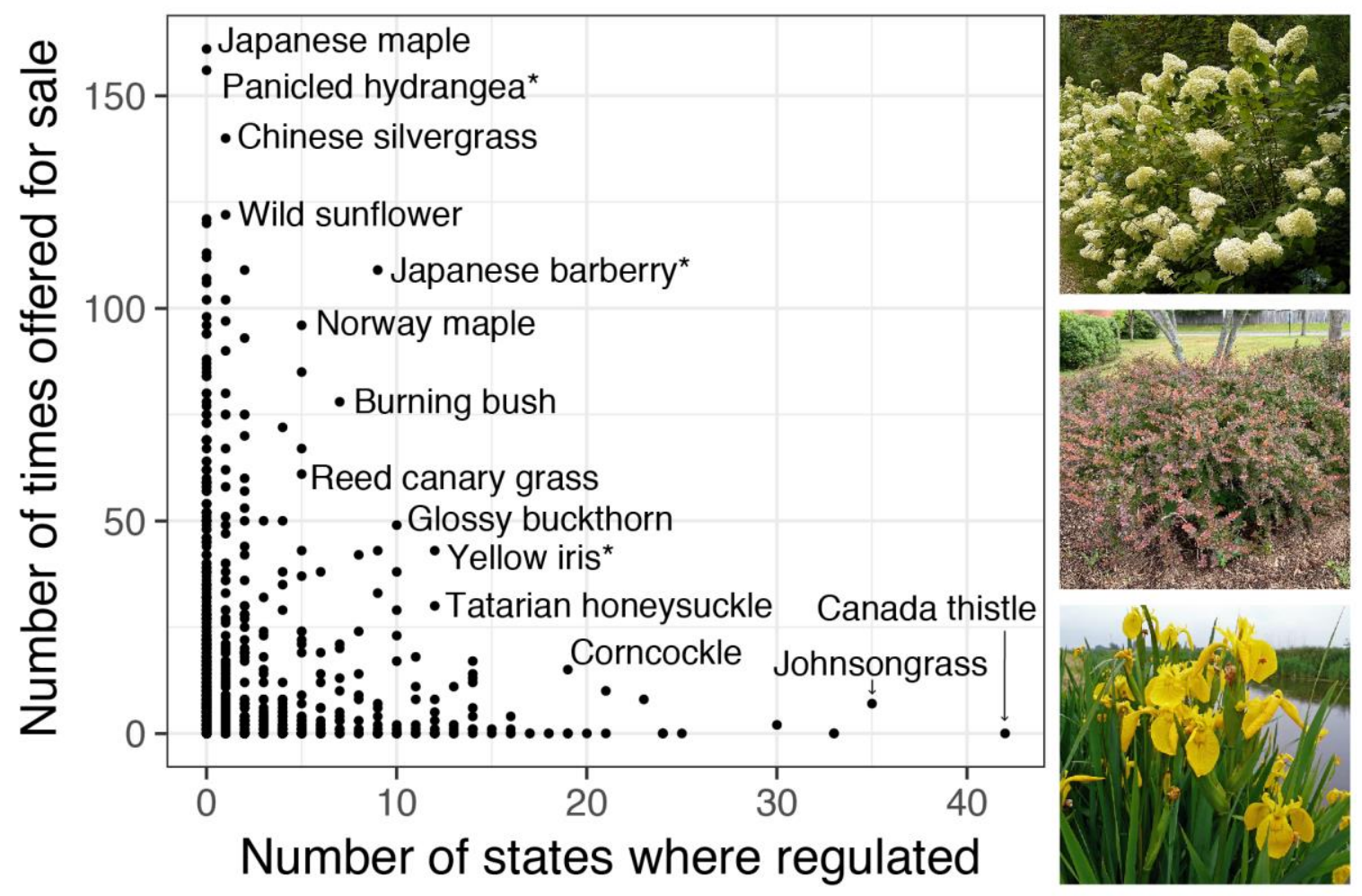

Figure 2. The number of vendors offering each species for sale versus the number of states in which the species was regulated. Asterisks indicate species pictured on the right. Top: panicled hydrangea (Hydrangea paniculata; photo by F Vincentz); middle: Japanese barberry (Berberis thunbergii; photo by E Beaury); bottom: yellow iris (Iris pseudacorus; photo by J Billinger).

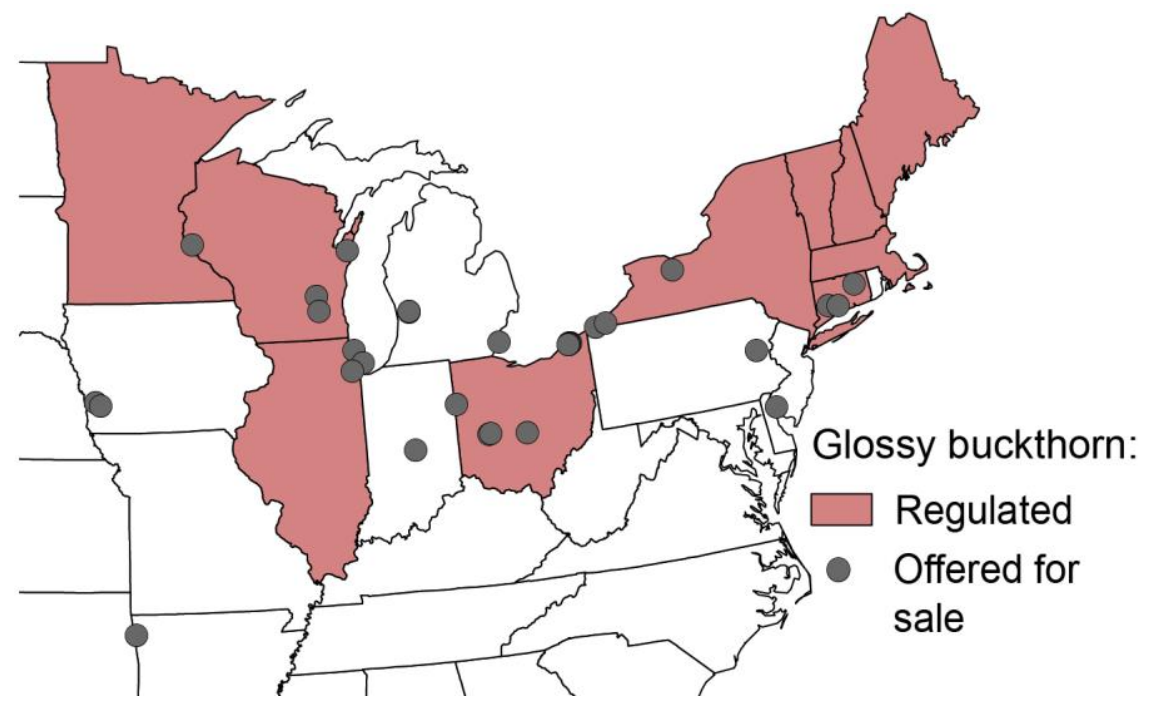

Figure 3. Locations of vendors selling glossy buckthorn (Frangula alnus) in the northeastern US, including within states where buckthorn is regulated. 
Table 1. Count and percentage of invasive plants available for purchase as ornamentals within the continental US

\begin{tabular}{lccc}
\hline List & $\begin{array}{c}\text { Number of species } \\
\text { searched }\end{array}$ & $\begin{array}{c}\text { Number of species } \\
\text { available for purchase }\end{array}$ & $\begin{array}{c}\text { Percentage of species } \\
\text { available for purchase }\end{array}$ \\
\hline Regulated species* & 688 & 343 & $50 \%$ \\
Unregulated species & 597 & 435 & $73 \%$ \\
Imported ornamentals $^{+}$ & 434 & 360 & $83 \%$ \\
All species & 1285 & 778 & $61 \%$ \\
\hline
\end{tabular}

Notes: *includes federal noxious weeds $\left(n=98,20\right.$ found for sale); ${ }^{+}$species originally introduced into the US as ornamentals. 